\title{
Leptin and energy restriction induced adaptation in energy expenditure
}

Citation for published version (APA):

Camps, S. G., Verhoef, S. P., \& Westerterp, K. R. (2015). Leptin and energy restriction induced adaptation in energy expenditure. Metabolism-Clinical and Experimental, 64(10), 1284-1290. https://doi.org/10.1016/j.metabol.2015.06.016

Document status and date:

Published: 01/01/2015

DOI:

10.1016/j.metabol.2015.06.016

Document Version:

Publisher's PDF, also known as Version of record

Document license:

Taverne

Please check the document version of this publication:

- A submitted manuscript is the version of the article upon submission and before peer-review. There can be important differences between the submitted version and the official published version of record.

People interested in the research are advised to contact the author for the final version of the publication, or visit the DOI to the publisher's website.

- The final author version and the galley proof are versions of the publication after peer review.

- The final published version features the final layout of the paper including the volume, issue and page numbers.

Link to publication

\footnotetext{
General rights rights.

- You may freely distribute the URL identifying the publication in the public portal. please follow below link for the End User Agreement:

www.umlib.nl/taverne-license

Take down policy

If you believe that this document breaches copyright please contact us at:

repository@maastrichtuniversity.nl

providing details and we will investigate your claim.
}

Copyright and moral rights for the publications made accessible in the public portal are retained by the authors and/or other copyright owners and it is a condition of accessing publications that users recognise and abide by the legal requirements associated with these

- Users may download and print one copy of any publication from the public portal for the purpose of private study or research.

- You may not further distribute the material or use it for any profit-making activity or commercial gain

If the publication is distributed under the terms of Article $25 \mathrm{fa}$ of the Dutch Copyright Act, indicated by the "Taverne" license above, 


\title{
Leptin and energy restriction induced adaptation in energy expenditure
}

\author{
Stefan G.J.A. Camps*, Sanne P.M. Verhoef, Klaas R. Westerterp \\ Department of Human Biology, NUTRIM School of Nutrition and Translational Research in Metabolism, 6200 MD, Maastricht, The Netherlands
}

\section{A R T I C L E I N F O}

Article history:

Received 4 February 2015

Accepted 22 June 2015

Keywords:

Leptin

Resting energy expenditure

Adaptive thermogenesis

Physical activity

Movement economy

\section{A B S T R A C T}

Background. Diet-induced weight loss is accompanied by adaptive thermogenesis, i.e. a disproportional reduction of resting energy expenditure (REE) a decrease in physical activity and increased movement economy.

Objective. To determine if energy restriction induced adaptive thermogenesis and adaptations in physical activity are related to changes in leptin concentrations.

Methods. Eighty-two healthy subjects (23 men, 59 women), mean \pm SD age $41 \pm 8$ years and BMI $31.9 \pm 3.0 \mathrm{~kg} / \mathrm{m}^{2}$, followed a very low energy diet for 8 weeks with measurements before and after the diet. Leptin concentrations were determined from fasting blood plasma. Body composition was assessed with a three-compartment model based on body weight, total body water (deuterium dilution) and body volume (BodPod). REE was measured (REEm) with a ventilated hood and predicted (REEp) from measured body composition. Adaptive thermogenesis was calculated as REEm/REEp. Parameters for the amount of physical activity were total energy expenditure expressed as a multiple of REEm (PAL), activity-induced energy expenditure divided by body weight (AEE/kg) and activity counts measured by a tri-axial accelerometer. Movement economy was calculated as AEE/ $\mathrm{kg}$ (MJ/kg/d) divided by activity counts (Mcounts/d).

Results. Subjects lost on average $10.7 \pm 4.1 \%$ body weight $(\mathrm{P}<0.001)$. Leptin decreased from $26.9 \pm 14.3$ before to $13.9 \pm 11.3 \mu \mathrm{g} / \mathrm{l}$ after the $\operatorname{diet}(\mathrm{P}<0.001)$. REEm/REEp after the diet $(0.963 \pm 0.08)$ was related to changes in leptin levels $\left(R^{2}=0.06 ; P<0.05\right)$. There was no significant correlation between changes in leptin concentrations and changes in amount of physical activity. Movement economy changed from $0.036 \pm 0.011 \mathrm{~J} / \mathrm{kg} /$ count to $0.028 \pm 0.010 \mathrm{~J} / \mathrm{kg} /$ count and was correlated to the changes in leptin concentrations $\left(R^{2}=0.07 ; P<0.05\right)$.

Conclusion. During energy restriction, the decrease in leptin explains part of the variation in adaptive thermogenesis. Changes in leptin are not related to the amount of physical activity but could partly explain the increased movement economy.

(c) 2015 Elsevier Inc. All rights reserved.

\section{Introduction}

Energy restriction induced weight loss is characterized by changes that promote a positive energy balance and cause the susceptibility for weight regain. On one side, appetite is elevated until the lost weight is regained [1-4]. On the other side, a decrease in total energy expenditure is often described. Studies performed in lean and obese subjects have shown

Abbreviations: TEE, total energy expenditure; REE, resting energy expenditure; AEE, activity induced energy expenditure; FFM, fat free mass; FM, fat mass; PAL, physical activity level.

* Corresponding author at: Maastricht University, Department of Human Biology, NUTRIM School of Nutrition and Translational Research in Metabolism, PO Box 616, 6200 MD, Maastricht, The Netherlands. Tel.: +31 43 3881617; fax: +31 433670976.

E-mail address: sg.camps@maastrichtuniversity.nl (S.G.J.A. Camps). 
significant reductions in resting energy expenditure (REE) during and shortly after weight loss, to values below predictions based on weight loss and body composition changes [5-10]. The decrease in REE beyond what can be predicted by the loss of fat-free mass (FFM) and fat mass (FM) is defined as adaptive thermogenesis. Additionally, several studies demonstrated a decrease in physical activity and activity induced energy expenditure (AEE) as a result of weight loss [11-15] as well as increased movement economy and skeletal muscle work efficiency [5,16]. Leibel stated that the hyperphagic, hypometabolic phenotype of weight-reduced humans is similar to that of leptin-deficient or leptin-unresponsive rodents [17].

Energy restriction and maintenance of reduced body weight are accompanied by declines in circulating leptin concentrations [18]. This reduction in leptin is seen with different protocols to induce weight loss, indicating a consistent effect $[19,20]$. Experiments in mice revealed that part of the physiological response to weight loss can be prevented by leptin injections [21]. Subsequent research in humans has indicated that administration of leptin that restores circulating leptin to levels present before weight loss reversed the increased energy intake [22] and decreased energy expenditure [23] as well as changes in sympathetic nervous system tone, thyroid function and movement economy [24]. It is now believed that leptin or similar drug treatment may decrease or diminish the negative physiological consequence of energy restriction and could lead to more successful weight maintenance [25].

Linking adaptive thermogenesis, the decrease in physical activity and increased movement economy to changes in leptin concentrations during weight loss will give further insight in the underlying mechanisms and the pharmacotherapeutic relevance of the focus on leptin. The aim of this study was to determine if energy restriction induced adaptive thermogenesis, change in physical activity and increased movement economy is related to changes in leptin concentrations.

\section{Subjects and Methods}

\subsection{Subjects}

Eighty-two healthy subjects (59 women and 23 men) with a mean age of $41 \pm 8$ years and with a mean body mass index (BMI) of $31.9 \pm 3.0 \mathrm{~kg} / \mathrm{m}^{2}$ were recruited by advertisements in local newspapers and on notice boards at the university. They underwent an initial screening that included measurements of body weight and height and the completion of a questionnaire on general health. All were in good health, not using medication (except for contraception), nonsmokers and at most moderate alcohol consumers. They were weight stable as defined by a weight change $<5 \mathrm{~kg}$ for at least 3 months prior to the study. The study was conducted according to the guidelines laid down in the Declaration of Helsinki and procedures were approved by the Ethics Committee of the Maastricht University Medical Centre. Written informed consent was obtained from all participants.

Clinical Trial Registration Number: NCT01015508 at clinicaltrials.gov.

\subsection{Study Design}

The study consisted of a very low energy diet for 8 weeks. Subjects came to the university for measurements on two occasions: the day before the start of the diet (baseline) and 8 weeks after the start of the diet (end of the diet). On each occasion, measurements included REE followed by body composition and the collection of a blood sample and were performed from 8:00 in the morning onwards in the fasting state. Total energy expenditure (TEE) and activity counts were measured during the two weeks prior to each measurement point.

\subsection{Diet}

The weight loss diet (Modifast; Nutrition et Santé Benelux, Breda, The Netherlands) was followed for a period of 8 weeks. The diet was a protein-enriched formula that provided 2.1 MJ/ day (51.9 grams of protein, 50.2 grams of carbohydrates and 6.9 grams of lipids) and a micronutrient content, which meets the Dutch recommended daily allowance. The very low energy diet was provided to the subjects as sachets with powder. Each sachet represented one meal and 3 sachets were consumed every day. Besides the provided mealreplacements, subjects were allowed to eat vegetables when feeling hungry. Subjects were instructed to mix the powder with the amount of water indicated on the packages and were advised to drink water sufficiently throughout the diet period.

\subsection{Body Composition}

Height was measured at screening to the nearest $0.1 \mathrm{~cm}$ with the use of a wall-mounted stadiometer (model 220; Seca, Hamburg, Germany). Body composition was determined according to Siri's three-compartment model based on body weight, body volume and total body water [26]. Body weight was measured using a calibrated scale (Life Measurement Corporation, Concord, CA). Body volume was measured via air-displacement plethysmography with the BodPod System (Life Measurement Corporation) $[27,28]$. Total body water was determined using deuterium dilution during the preceding night, according to the Maastricht protocol [29]. Body mass index (BMI) was calculated by dividing body weight by height squared $\left(\mathrm{kg} / \mathrm{m}^{2}\right)$.

\subsection{Energy Expenditure}

To reach the university for REE measurements, subjects were instructed to travel by public transport or by car to avoid physical activity that would increase REE. After arrival, they rested on a bed for 30 minutes, followed by 30 minutes of measuring their REE in the supine position using an opencircuit ventilated hood-system [30]. Gas analyses were performed by a paramagnetic oxygen analyzer (Servomex, type 500A, Crowborough, East Sussex, UK) and an infrared carbon dioxide analyzer (Servomex, type 500A, Crowborough, East Sussex, UK) while flow was kept at a constant rate of $80 \mathrm{l} / \mathrm{min}$ and additionally measured as described by Schoffelen et al. [31]. The within individual coefficient of variation for this system is $3.3 \% \pm 2.1$ [30]. Calculation of REE from measured oxygen consumption and carbon dioxide production was based on Brouwer's formula [32]. 
TEE $(\mathrm{n}=38)$ was measured over two weeks intervals with the doubly labeled water method according to the Maastricht protocol [29]. On the evening of day 1, shortly after the collection of a background urine sample, subjects drank a weighed amount of ${ }^{2} \mathrm{H}_{2}^{18} \mathrm{O}$ such that baseline levels were increased by $100-150 \mathrm{ppm}$ for ${ }^{2} \mathrm{H}$ and $200-250 \mathrm{ppm}$ for ${ }^{18} \mathrm{O}$. Subsequently, urine samples were collected in the morning of day 2 (second voiding), day 8 and day 14 and in the evening of days 1,8 and 13 . The doubly labeled water method gives precise and accurate information on carbon dioxide $\left(\mathrm{CO}_{2}\right)$ production. $\mathrm{CO}_{2}$ production was subsequently converted to TEE with the use of the energy equivalent of $\mathrm{CO}_{2}$, which can be calculated with additional information on the substrate mixture being oxidized [33]. The energy equivalent at baseline was calculated based on a normal Western diet with a mixed macronutrient composition and energy respectively for $55 \%$ from carbohydrate, $30 \%$ from fat and $15 \%$ from protein. At the end of the diet, the energy equivalent of $\mathrm{CO}_{2}$ was based on the consumption of the Modifast diet, the actual loss of fat mass and fat free mass and additional energy intake. The additional food intake was the calculated compensation for the difference between weight loss and the expected weight loss based on the consumption of the Modifast diet alone, with the assumption of $1 \mathrm{~kg}$ weight change to be equivalent to $30 \mathrm{MJ}$ [34]. The additional food intake was also assumed to be a normal mixed diet.

At baseline, AEE was calculated as $(0.9 \times \mathrm{TEE})-\mathrm{REE}$, assuming diet induced thermogenesis to be $10 \%$ of TEE, which is based on a normal mixed diet [35] and diet induced thermogenesis values for the separate macronutrients to be $10 \%$ for carbohydrate, $3 \%$ for fat and $25 \%$ for protein. At the end of the diet, the percentage diet induced thermogenesis was calculated based on the intake of the Modifast diet and the additional food intake with a normal mixed composition, which accounted for the difference between the expected weight loss and the real weight loss. Diet induced thermogenesis was calculated to be $8 \%$ of the TEE at the end of the diet; therefore AEE was calculated as $(0.92 \times$ TEE) - REE.

The physical activity level was calculated PAL $=$ TEE/REE [36]. AEE was adjusted for body weight $\left(\mathrm{AEE}_{\mathrm{kg}}=\mathrm{AEE} / \mathrm{BM}\right)$ to normalize the energy expenditure of physical activity [37].

\subsection{Physical Activity Monitoring}

Physical activity was monitored over two-week intervals using the previously validated DirectLife triaxial accelerometer (DirectLife, Philips Consumer Lifestyle, Amsterdam, The Netherlands). The device is small and lightweight and was carried at an elastic belt around the waist. Subjects were instructed to wear the accelerometer during waking hours, except during showering and water activities. A diary was used to report periods in which the subject was not wearing the accelerometer during the day. The accelerometer output was processed to determine body movement by measuring activity counts. Total activity counts were calculated over the two-week monitoring period, and the sum of counts was divided by the number of monitoring days to determine the average activity counts per day [38,39]. Days during which data were missing or subjects carried the accelerometer for $<10 \mathrm{~h}$ were excluded and the average was calculated on the remaining data, considering daily physical activity an ergodic process. Subjects with at least seven valid days were included. Following these criteria, no subject was excluded.

\subsection{Movement Economy}

Movement economy was calculated as AEE/kg (MJ/kg/d) divided by the activity counts (Mcounts/d). The outcome is expressed as $\mathrm{J} / \mathrm{kg} /$ count.

\subsection{Blood Parameters}

Fasted blood samples were taken and collected in EDTA containing tubes to prevent clotting. Plasma was obtained by centrifugation and stored at $-80^{\circ} \mathrm{C}$ until further analysis. Leptin concentrations were measured with the use of human RIA kit (Millipore, St. Charles, MO) with a detection limit of $0.5 \mathrm{ng} / \mathrm{ml}$, an inter-assay precision of $3.6-6.2 \%$ and an intraassay precision of $3.4-8.3 \%$.

\subsection{Calculations and Statistical Analysis}

In addition to measuring REE with the ventilated hood system (REEm), REE was predicted (REEp) with the equation: REEp (M)/ d) $=0.024 \times$ fat mass $(\mathrm{kg})+0.102 \times$ fat free mass $\times(\mathrm{kg})+0.85$ [40]. Since FM and FFM are used to calculate REEp, the equation can be used independently for gender. Adaptive thermogenesis was calculated as REEm divided by REEp. The obtained ratio was then compared between the different time points. A value above 1 indicates that measured REE is higher than what is expected based on the body composition, and a value lower than 1 indicates that measured REE is lower than what is expected based on the body composition. One-way repeated measures ANOVA with Bonferroni adjustment for multiple comparisons and one-way between-groups analysis of covariance (ANCOVA) were used to compare the variables across 0 and 8 weeks.

Multiple hierarchical regression analysis has been performed to determine relations and interactions between dependant and independent variables. Age, gender, baseline FM (kg), baseline FFM (kg), change in FM (kg), change in FFM $(\mathrm{kg})$ and baseline dependant variable were used as covariates in all tests; the regression model combining these recurring variables is referred to as the combined model.

The data were analyzed using SPSS 20.0 (SPSS, Chicago, IL). All data are presented as mean and standard deviation (SD).

\section{Results}

Subject characteristics at baseline and the results on body composition, energy expenditure, physical activity, movement economy and leptin after the 8 weeks very low energy diet are provided in Table A.1.

\subsection{Interaction}

The combined model including age, gender, baseline body composition, changes in body composition and baseline value of the dependant variable explained part $47 \%$ of the variance in the change in REEm after 8 weeks of $\operatorname{diet}(\mathrm{P}<0.001)$ with no 
significant additional value of the change in leptin concentration (Table A.2).

Six percent of the variation in REEm/REEp after the diet was explained by the decrease in leptin $(\mathrm{P}<0.05)$ on top of the explained variation by the combined model $\left(R^{2}=0.35 ; P<0.001\right)$.

The combined model explained $61 \%$ of the variation in the change in PAL $(\mathrm{P}<0.001), 59 \%$ of the change in $\mathrm{AEE} / \mathrm{kg}$ $(\mathrm{P}<0.001)$ and $23 \%$ of the change in activity counts $(\mathrm{P}<0.01)$ after 8 weeks of diet, with no significant additional explanation from the change in leptin concentration.

Seven percent of the variation in AEE/kg/activity counts after the diet was explained by the decrease in leptin $(\mathrm{P}<0.05)$ on top of the explained variation by the combined model $\left(R^{2}=0.69 ; P<0.001\right)$.

\section{Discussion}

Measuring energy expenditure, physical activity and circulating leptin concentration before and after a diet showed that the decrease in leptin in response to energy restriction is significantly and independently related to the greater than expected decrease in resting energy expenditure. The decrease in leptin is not correlated to the reduction in the amount of physical activity, however leptin is independently correlated to the increased movement economy. These results indicate that the change in plasma leptin levels could be part of the underlying mechanism explaining more efficient resting energy expenditure and more efficient physical activity during energy restriction.

Energy restriction leads to a decrease in REE of which only a part can be attributed to the change in body composition. The greater decline is often indicated as adaptive thermogenesis. In accordance with previous findings, our results show a four percent greater decline in REE than expected from the diet-induced weight loss, which was correlated to the change in body composition $[5,10,41,42]$. In addition to these results, the energy restriction induced change in leptin concentration was independently related to the adaptive response, indicating that a greater decrease in leptin correlates with, and could partly explain a greater disproportionate reduction in REE. Previously, leptin had been shown to be correlated to the weight loss induced decrease of REE [43,44]; our results specifically indicate a relation with adaptive thermogenesis, in line with Lecoultre et al. [45]. Rosenbaum et al. showed that leptin administration during a weight-reduced state returned energy expenditure to pre-weight loss levels [23,24]. The combined results suggest a central role for leptin in the underlying mechanisms of metabolic adaptation, where a leptin associated decrease in sympathetic nervous activity seems an important mediator [46], still the exact mechanism remains speculative $[17,47]$.

Energy restriction and weight loss are associated with a reduction in physical activity [11-13] and increased movement economy $[5,16]$ as well. Our results showed a decline of physical activity during the diet and an increase in movement economy, expressed as AEE per kilogram body weight per activity count. Furthermore, there is no significant correlation between the decrease in leptin and the decrease in the amount of physical activity. However, the results do show an independent correlation of the change in leptin levels and the increase in movement economy. In accordance with our results, Doucet et al. described a relation between the changes in leptin concentration and the difference between the predicted and the measured fall in net exercise energy expenditure [48]. This implies that leptin does not play a role in the reduction of the amount of physical activity but that it points toward an effect on increased movement economy during energy restriction. Although the exact mechanism is not clear, a decrease in sympathetic nervous activity related to leptin during weight loss seems an important mediator $[46,47]$.

A limitation of this study is generated by the interindividual variation in the results. However, the observed variation allowed the induced metabolic adaptation to be correlated to a range from less to more successful weight loss and change in leptin levels. With regard to leptin, the researchers understand that 24-h leptin concentrations are preferable but indicate fasting leptin levels are a sufficient measure in a longitudinal study. The presence of a control group with subjects of similar BMI but not subjected to a very low energy diet would have been valuable. Another limitation is that interpreting PAL values during weight changes may be affected by the effect of weight loss on RMR. However, there is no indication for a significant change in the results and moreover, PAL results are in line with the results expressed as AEE/kg and activity counts. One of the main strengths of this study is the use of the gold standard in measuring free-living TEE: doubly labeled water. Therefore, PAL, AEE and AEE/kg reflect the physical activity and energy expenditure in normal daily life and are not confounded by restrictions of body movement. A second strength is the use of two independent methods based on measurement of energy expenditure and body movement.

In conclusion, this study indicates that the change in plasma leptin levels could be part of the underlying mechanism explaining more efficient resting energy expenditure and increased movement economy during energy restriction. Though, the decrease in leptin does not seem to affect the decline in the amount of physical activity during a diet. This confirms leptin as an important target for drug treatment, to diminish the negative physiological consequence of energy restriction and improve weight maintenance.

\section{Author Contribution}

K.R. Westerterp and S.P.M. Verhoef designed the study. S.G.J.A. Camps and S.P.M. Verhoef collected the data. S.G.J.A. Camps analyzed the data and wrote the manuscript. K.R. Westerterp contributed to the interpretation of the data and reviewed the manuscript. The study was executed under supervision of K.R. Westerterp. All authors read and approved the final manuscript. None of the authors had any conflict of interest.

\section{Funding}

Maastricht University.

\section{Disclosure Statement}

The authors have nothing to disclose. 


\section{Appendix A}

\section{Table A.1 - Subject characteristics (mean \pm SD) at baseline, after 8 weeks on a very low energy diet.}

\begin{tabular}{|c|c|c|}
\hline & Baseline $(\mathrm{n}=82)$ & $8 \mathrm{wk}(\mathrm{n}=82)$ \\
\hline Weight (kg) & $92.8 \pm 11.9$ & $83.5 \pm 11.0^{* * *}$ \\
\hline FM (kg) & $38.9 \pm 7.6$ & $31.5 \pm 7.8^{* * * *}$ \\
\hline FFM (kg) & $53.8 \pm 9.3$ & $51.9 \pm 8.9^{* * *}$ \\
\hline $\operatorname{REEm}(\mathrm{MJ} / \mathrm{d})$ & $7.29 \pm 1.01$ & $6.63 \pm 0.88^{* * *}$ \\
\hline REEp (MJ/d) & $7.27 \pm 0.96$ & $6.90 \pm 0.90^{* * *}$ \\
\hline REEm/REEp & $1.004 \pm 0.077$ & $0.963 \pm 0.073^{* * *}$ \\
\hline REEm/REEp adj. & & $0.967 \pm 0.007^{*}$ \\
\hline $\operatorname{AEE}(M J / d)$ & $5.17 \pm 1.64$ & $3.64 \pm 1.49^{* * *}$ \\
\hline PAL & $1.69 \pm 0.23$ & $1.52 \pm 0.19^{* * *}$ \\
\hline $\mathrm{AEE} / \mathrm{kg}$ & $0.056 \pm 0.018$ & $0.043 \pm 0.016^{* * *}$ \\
\hline Mcounts/d & $1.61 \pm 0.39$ & $1.54 \pm 0.39^{* *}$ \\
\hline AEE/kg/activity counts (J/kg/count) & $0.037 \pm 0.011$ & $0.028 \pm 0.010^{* * *}$ \\
\hline Leptin $(\mu \mathrm{g} / \mathrm{L})$ & $26.9 \pm 14.3$ & $13.9 \pm 11.3^{* * *}$ \\
\hline \multicolumn{3}{|c|}{$\begin{array}{l}\text { One-way repeated measures ANOVA with Bonferroni adjustment for multiple comparisons and one-way between-groups analysis of } \\
\text { covariance (ANCOVA) were used to compare the variables across } 0 \text { and } 8 \text { weeks. } \\
\text { FM, fat mass; FFM, fat free mass; REEm, measured resting energy expenditure; REEp, predicted resting energy expenditure; REEm/REEp, adjusted } \\
\text { for weight loss percentage }( \pm \text { SE); AEE, activity induced energy expenditure; PAL, physical activity level. } \\
{ }^{*} \mathrm{P}<0.05 \text { compared with baseline. } \\
{ }^{* *} \mathrm{P}<0.01 \text { compared with baseline. } \\
{ }^{* * *} \mathrm{P}<0.001 \text { compared with baseline. }\end{array}$} \\
\hline
\end{tabular}

Table A.2 - Multiple regression results of a model combining age, gender, baseline fat mass, baseline fat free mass, fat mass loss, fat free mass loss, baseline dependent variable and change in leptin concentration to predict changes after 8 weeks on a very low energy diet.

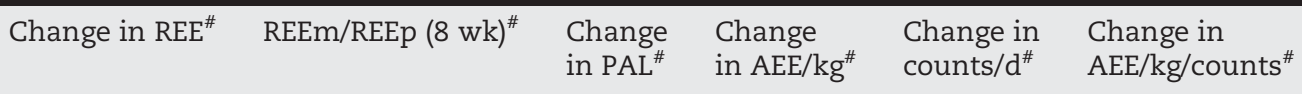

Age

Gender

Baseline FM $0.03^{*}$

Baseline FFM $0.05^{*}$

Change in FM

Change in FFM $0.05^{*}$

0.05

Baseline dependent variable ${ }^{\#} \quad 0.24^{* * *} \quad 0.22^{* *}$

Change in leptin

Total

$0.47^{* * *}$

$0.06^{*}$

$\begin{array}{llll}0.45^{* * *} & 0.41^{* * *} & 0.21^{* * *} & 0.08^{*} \\ & & & 0.50^{* * *} \\ 0.61^{* * *} & 0.59^{* * *} & 0.23^{* * *} & 0.07^{* * *}\end{array}$

Multiple regression analysis results in predicting variation in the change in REE, 8-week REEm/REEp, change in PAL, change in AEE/kg, change in activity counts/d and change in AEE/kg/count (change is the difference between before and after the diet).

Significant $\mathrm{R}^{2}$-values are shown for age, gender, baseline fat mass, baseline fat free mass, fat mass loss, fat free mass loss, baseline dependent variable and change in leptin concentration as well as the total model.

REEm, measured resting energy expenditure; REEp, predicted resting energy expenditure; PAL, physical activity level; AEE, activity induced energy expenditure; FM, fat mass; FFM, fat free mass.

${ }^{*} \mathrm{P}<0.05$.

${ }^{* * *} \mathrm{P}<0.001$ 


\section{REFEREN C ES}

[1] Anton SD, Han H, York E, Martin CK, Ravussin E, Williamson DA. Effect of calorie restriction on subjective ratings of appetite. J Hum Nutr Diet 2009;22:141-7.

[2] Doucet E, Imbeault P, St-Pierre S, Almeras N, Mauriege P, Richard D, et al. Appetite after weight loss by energy restriction and a low-fat diet-exercise follow-up. Int J Obes Relat Metab Disord 2000;24:906-14.

[3] Dulloo AG, Calokatisa R. Adaptation to low calorie intake in obese mice: contribution of a metabolic component to diminished energy expenditures during and after weight loss. Int J Obes 1991;15:7-16.

[4] Levin BE, Dunn-Meynell AA. Defense of body weight against chronic caloric restriction in obesity-prone and -resistant rats. Am J Physiol Regul Integr Comp Physiol 2000;278:R231-7.

[5] Leibel RL, Rosenbaum M, Hirsch J. Changes in energy expenditure resulting from altered body weight. N Engl J Med 1995;332:621-8.

[6] Dulloo AG, Jacquet J. Adaptive reduction in basal metabolic rate in response to food deprivation in humans: a role for feedback signals from fat stores. Am J Clin Nutr 1998;68: 599-606.

[7] Schwartz A, Doucet E. Relative changes in resting energy expenditure during weight loss: a systematic review. Obes Rev 2010;11:531-47.

[8] Tremblay A, Chaput JP. Adaptive reduction in thermogenesis and resistance to lose fat in obese men. Br J Nutr 2009;102:488-92.

[9] Weyer C, Walford RL, Harper IT, Milner M, MacCallum T, Tataranni PA, et al. Energy metabolism after 2 y of energy restriction: the biosphere 2 experiment. Am J Clin Nutr 2000; 72:946-53.

[10] Camps SG, Verhoef SP, Westerterp KR. Weight loss, weight maintenance, and adaptive thermogenesis. Am J Clin Nutr 2013;97:990-4.

[11] Camps SG, Verhoef SP, Westerterp KR. Weight loss induced reduction in physical activity recovers during weight maintenance. Am J Clin Nutr 2013;98:917-23.

[12] de Groot LC, van Es AJ, van Raaij JM, Vogt JE, Hautvast JG. Adaptation of energy metabolism of overweight women to alternating and continuous low energy intake. Am J Clin Nutr 1989;50:1314-23.

[13] Martin CK, Heilbronn LK, de Jonge L, DeLany JP, Volaufova J, Anton SD, et al. Effect of calorie restriction on resting metabolic rate and spontaneous physical activity. Obesity (Silver Spring) 2007;15:2964-73.

[14] Redman LM, Heilbronn LK, Martin CK, de Jonge L, Williamson DA, Delany JP, et al. Metabolic and behavioral compensations in response to caloric restriction: implications for the maintenance of weight loss. PLoS One 2009;4:e4377.

[15] Bonomi AG, Soenen S, Goris AH, Westerterp KR. Weight-loss induced changes in physical activity and activity energy expenditure in overweight and obese subjects before and after energy restriction. PLoS One 2013;8:e59641.

[16] Rosenbaum M, Vandenborne K, Goldsmith R, Simoneau JA, Heymsfield S, Joanisse DR, et al. Effects of experimental weight perturbation on skeletal muscle work efficiency in human subjects. Am J Physiol Regul Integr Comp Physiol 2003;285:R183-92.

[17] Leibel RL. The role of leptin in the control of body weight. Nutr Rev 2002;60:S15-9 [discussion S68-84, 85-7].

[18] Rosenbaum M, Nicolson M, Hirsch J, Murphy E, Chu F, Leibel RL. Effects of weight change on plasma leptin concentrations and energy expenditure. J Clin Endocrinol Metab 1997;82: 3647-54.

[19] Sumithran P, Prendergast LA, Delbridge E, Purcell K, Shulkes A, Kriketos A, et al. Long-term persistence of hormonal adaptations to weight loss. N Engl J Med 2011;365:1597-604.
[20] Ozcelik O, Dogan H, Celik H, Ayar A, Serhatlioglu S, Kelestimur H. Effects of different weight loss protocols on serum leptin levels in obese females. Physiol Res 2005;54: 271-7.

[21] Ahima RS, Prabakaran D, Mantzoros C, Qu D, Lowell B, Maratos-Flier E, et al. Role of leptin in the neuroendocrine response to fasting. Nature 1996;382:250-2.

[22] Rosenbaum M, Sy M, Pavlovich K, Leibel RL, Hirsch J. Leptin reverses weight loss-induced changes in regional neural activity responses to visual food stimuli. J Clin Invest 2008; 118:2583-91.

[23] Rosenbaum M, Murphy EM, Heymsfield SB, Matthews DE, Leibel RL. Low dose leptin administration reverses effects of sustained weight-reduction on energy expenditure and circulating concentrations of thyroid hormones. J Clin Endocrinol Metab 2002;87:2391-4.

[24] Rosenbaum M, Goldsmith R, Bloomfield D, Magnano A, Weimer L, Heymsfield S, et al. Low-dose leptin reverses skeletal muscle, autonomic, and neuroendocrine adaptations to maintenance of reduced weight. J Clin Invest 2005; 115:3579-86.

[25] Paz-Filho G, Mastronardi CA, Licinio J. Leptin treatment: facts and expectations. Metabolism 2015;64:146-56.

[26] Siri WE. Body composition from fluid spaces and density: analysis of methods. 1961. Nutrition 1993;9:480-91 [discussion 480, 492].

[27] Ginde SR, Geliebter A, Rubiano F, Silva AM, Wang J, Heshka S, et al. Air displacement plethysmography: validation in overweight and obese subjects. Obes Res 2005;13:1232-7.

[28] Dempster P, Aitkens S. A new air displacement method for the determination of human body composition. Med Sci Sports Exerc 1995;27:1692-7.

[29] Westerterp KR, Wouters L, van Marken Lichtenbelt WD. The Maastricht protocol for the measurement of body composition and energy expenditure with labeled water. Obes Res 1995;3(Suppl. 1):49-57.

[30] Adriaens MP, Schoffelen PF, Westerterp KR. Intra-individual variation of basal metabolic rate and the influence of daily habitual physical activity before testing. Br J Nutr 2003;90: 419-23.

[31] Schoffelen PF, Westerterp KR, Saris WH, Ten Hoor F. A dual-respiration chamber system with automated calibration. J Appl Physiol 1997;83:2064-72.

[32] Brouwer E. On simple formulae for calculating the heat expenditure and the quantities of carbohydrate and fat oxidized in metabolism of men and animals, from gaseous exchange (oxygen intake and carbonic acid output) and urine-N. Acta Physiol Pharmacol Neerl 1957;6:795-802.

[33] Black A, Prentice A, Coward W. Use of food quotients to predict respiratory quotients for the doubly-labelled water method of measuring energy expenditure. Hum Nutr Clin Nutr 1986;40:381-91.

[34] Westerterp KR. Physical activity, food intake, and body weight regulation: insights from doubly labeled water studies. Nutr Rev 2010;68:148-54.

[35] Westerterp KR. Impacts of vigorous and non-vigorous activity on daily energy expenditure. Proc Nutr Soc 2003;62:645-50.

[36] Westerterp KR, Plasqui G. Physical activity and human energy expenditure. Curr Opin Clin Nutr Metab Care 2004;7: 607-13.

[37] Schoeller DA, Jefford G. Determinants of the energy costs of light activities: inferences for interpreting doubly labeled water data. Int J Obes Relat Metab Disord 2002;26:97-101.

[38] Bonomi AG, Plasqui G, Goris AH, Westerterp KR. Estimation of free-living energy expenditure using a novel activity monitor designed to minimize obtrusiveness. Obesity (Silver Spring) 2010;18:1845-51.

[39] Bonomi AG, Plasqui G, Goris AH, Westerterp KR. Improving assessment of daily energy expenditure by identifying types 
of physical activity with a single accelerometer. J Appl Physiol 2009;107:655-61.

[40] Westerterp KR, Donkers JH, Fredrix EW, Boekhoudt P. Energy intake, physical activity and body weight: a simulation model. Br J Nutr 1995;73:337-47.

[41] Doucet E, St-Pierre S, Almeras N, Despres JP, Bouchard C, Tremblay A. Evidence for the existence of adaptive thermogenesis during weight loss. Br J Nutr 2001;85:715-23.

[42] Johannsen DL, Knuth ND, Huizenga R, Rood JC, Ravussin E, Hall $\mathrm{KD}$. Metabolic slowing with massive weight loss despite preservation of fat-free mass. J Clin Endocrinol Metab 2012;97.

[43] Doucet E, St Pierre S, Almeras N, Mauriege P, Richard D, Tremblay A. Changes in energy expenditure and substrate oxidation resulting from weight loss in obese men and women: is there an important contribution of leptin? J Clin Endocrinol Metab 2000;85:1550-6.

[44] Labayen I, Ortega FB, Ruiz JR, Lasa A, Simon E, Margareto J. Role of baseline leptin and ghrelin levels on body weight and fat mass changes after an energy-restricted diet intervention in obese women: effects on energy metabolism. J Clin Endocrinol Metab 2011;96:E996-1000.

[45] Lecoultre V, Ravussin E, Redman LM. The fall in leptin concentration is a major determinant of the metabolic adaptation induced by caloric restriction independently of the changes in leptin circadian rhythms. J Clin Endocrinol Metab 2011;96:E1512-6.

[46] Arone LJ, Mackintosh R, Rosenbaum M, Leibel RL, Hirsch J. Autonomic nervous system activity in weight gain and weight loss. Am J Physiol 1995;269:R222-5.

[47] Park HK, Ahima RS. Physiology of leptin: energy homeostasis, neuroendocrine function and metabolism. Metabolism 2015; 64:24-34.

[48] Doucet E, Imbeault P, St-Pierre S, Almeras N, Mauriege P, Despres JP, et al. Greater than predicted decrease in energy expenditure during exercise after body weight loss in obese men. Clin Sci (Lond) 2003;105:89-95. 